\title{
Tort Liability for Nonlibelous Negligent Statements: First Amendment Considerations
}

If a negligent physical act causes an injury, the tort-feasor, absent a defense of contributory negligence, is usually liable. If, however, that same injury is the result of some form of speech, ${ }^{1}$ the First Amendment could conceivably insulate the tort-feasor from liability. ${ }^{2}$ Two recent state supreme court decisions ${ }^{3}$ have barred recovery in such tort actions because the defendants' actions were deemed protected speech. By adopting the strict "incitement" standard of Brandenburg $v$. Ohio ${ }^{4}$ in one case, ${ }^{5}$ and the closely related "clear and present danger" test ${ }^{6}$ in the other, ${ }^{7}$ these courts have required a plaintiff to bear a heavy burden in proving culpable negligence.

This Note argues that the First Amendment should not impose so great a bar to recovery, and that the authors and publishers of nonlibelous negligent statements ${ }^{8}$ should be held liable in tort for the physical harm proximately caused by such statements. ${ }^{9}$ Instead of relying upon indeterminate

1. Assume that $X$ publishes a recipe for what turns out to be a poisonous cake, and $Y$ follows that recipe, eats the cake, and dies as a result. A similar, though less tragic, case has actually been reported. See Cardozo v. True, 342 So. 2d 1053 (Fla. Dist. Ct. App.) (plaintiff injured as a result of cookbook's inadequate warnings regarding poisonous ingredients used in recipe), cert. denied, 353 So. 2d 674 (Fla. 1977).

2. "Congress shall make no law . . . abridging the freedom of speech, or of the press . . . ."U.S. CoNST. amend. I. Admittedly, a suit to recover for damages resulting from the negligent use of language will not be based on a statute, but rather on common law tort principles. The First Amendment still applies since common law tort liability is a form of state action. See New York Times Co. v. Sullivan, 376 U.S. 254, 265 (1964) ("The test is not the form in which state power has been applied but, whatever the form, whether such power has in fact been exercised.").

3. Walt Disney Prods. v. Shannon, 247 Ga. 402, 276 S.E.2d 580 (1981); DeFilippo v. National Broadcasting Co., 446 A.2d 1036 (R.I. 1982).

4. 395 U.S. 444 (1969) (per curiam).

5. DeFilippo v. National Broadcasting Co., 446 A.2d 1036, 1040 (R.I. 1982).

6. The "clear and present danger" test was first articulated in Schenck v. United States, 249 U.S. 47, 52 (1919) (Holmes, J.) ("The question in every case is whether the words used are used in such circumstances and are of such a nature as to create a clear and present danger that they will bring about the substantive evils that Congress has a right to prevent.").

7. Walt Disney Prods. v. Shannon, 247 Ga. 402, 404, 276 S.E.2d 580, 582 (1981).

8. In this Note, the statements at issue will be referred to as "nonlibelous negligent statements." A nonlibelous negligent statement is a nondefamatory statement that, because of negligence in speaking, leads to injury even though no injury or law violation is intended or encouraged.

9. The analysis presented in this Note is directed almost exclusively toward "published" negligent speech that causes physical injury. Of course, negligent speech-whether published or unpublished-can cause a wide variety of injuries. For example, such speech can cause economic injury and injury to reputation, as well as physical injury. This Note is limited to published speech that causes physical harm because this is the one area in which no acceptable standards currently exist. The law of libel comprises a coherent body of law with respect to injury to reputation. Similarly, the law of 
"core" First Amendment principles to decide these cases, courts should employ the law of misrepresentation. ${ }^{10}$ The Note then proposes a standard for nonlibelous negligent speech, and concludes that a proper use of this standard will permit the compensation of many of the victims of published negligent speech while still keeping liability within the bounds of the First Amendment.

\section{The Cases and the Dilemma}

Several recent cases have struggled with the question of whether the First Amendment precludes the imposition of tort liability for nonlibelous negligent statements. In Walt Disney Productions v. Shannon, ${ }^{11}$ a child was injured while performing an experiment suggested by a guest on a children's television program. The court held that the case was governed by the "clear and present danger" standard of Schenck v. United States. ${ }^{12}$

deceit and misrepresentation already provides a proper framework of analysis for economic harm. Even with respect to physical injury caused by unpublished speech, an acceptable governing body of law is in place. See infra pp. 755-56. It is only when physically injurious speech is published that the courts lack adequate guidance.

10. While this Note argues that the First Amendment should have only a limited effect on liability for nonlibelous negligent statements, it does not suggest that the First Amendment is completely inapplicable. This conclusion has, however, been advanced by several commentators. See, e.g., Rountree, Constitutional Lau", 33 Mercer L. REv. 51, 63 (1981) ("it is hard to believe that what was claimed in Shannon has anything to do with the first amendment"); Wallis, "Negligent Publishing": Implications for Unitersity Publishers, 9 J. Col.L. \& U.L. 209, 225 (1982) ("A plaintiff might lassert] that the first amendment immunity was never intended to provide tort immunity for consumer injuries."). The statements at issue, however, typically involve the public dissemination of knowledge and information. See, e.g., Carter v. Rand McNally \& Co., No. 76-1864-F (D. Mass. Sept. 4, 1980) (chemistry textbook); Walt Disney Prods. v. Shannon, 247 Ga. 402, 276 S.E.2d 580 (1981) (televised sound effects experiment). The First Amendment supplies at least some protection in this context. See, P.g., Gertz v. Robert Welch, Inc., 418 U.S. 323, 340 (1974) (indicating that a rule that compels a publisher to guarantee the accuracy of his factual assertions would be unconstitutional); Demuth Dev. Corp. v. Merck \& Co., 432 F. Supp. 990, 993 (E.D.N.Y. 1977) (the "right to publish free of fear of liability is guaranteed by the First Amendment . . . and the overriding societal interest in the untrammeled dissemination of knowledge"); see also T. EMERSON, THE SYSTEM OF FREEDOM OF EXPRESSION 3 (1970) (among the rights making up our "present-day concept of free expression" is the right "to communicate ideas, opinions, and information through any medium") (emphasis added); Meiklejohn, The First Amendment Is an Absolute, 1961 Sup. Cr. REv. 245, 257 ("Freedom of education is . . . a basic postulate in the planning of a free society.").

Admittedly, not all of the cases regarding nonlibelous negligent statements involve attempts to disseminate information. Some cases involve communications intended solely as entertainment. See, e.g., Weirum v. RKO Gen., Inc., 15 Cal. 3d 40, 539 P.2d 36, 123 Cal. Rptr. 468 (1975) (radio giveaway contest); DeFilippo v. National Broadcasting Co., 446 A.2d 1036 (R.I. 1982) (televised hanging stunt). Still, even these statements are worthy of at least some First Amendment protection: "The line between the informing and the entertaining is too elusive for the protection of [a free press]. Everyone is familiar with instances of propaganda through fiction. What is one man's amusement, teaches another's doctrine." Winters v. New York, 333 U.S. 507, 510 (1948).

11. $247 \mathrm{Ga} .402$, 276 S.E.2d 580 (1981). The Shannon case has been discussed in several recent articles. See, P.g., Eldridge, Torts, 33 MERCER L. Rev. 247, 254 (1981) (hailing Shannon as "a landmark case"); Note, Broadcast Negligence and the First Amendment: Even Mickey Mouse Has Rights, 33 MERCER L. REv. 423, 432 (1981) (supporting the Shannon decision).

12. 249 U.S. 47, 52 (1919). Though the Shannon court used the "clear and present danger" test, it clearly felt that this test was analogous to the Brandenburg "incitement" standard. See Shannon, 
The Shannon court found no "clear and present danger" and, after expressing concern over the potential "chilling effect" of imposing tort liability, reversed a prior judgment against the defendants.

The Supreme Court of Rhode Island reached a similar conclusion in DeFilippo v. National Broadcasting Co., ${ }^{13}$ a case involving a child who died while imitating a hanging stunt he saw on television. Relying on Brandenburg $v$. Ohio ${ }^{14}$ the court held that the First Amendment barred recovery unless the plaintiffs could prove "incitement." ment" was proved in DeFilippo, the court dismissed the plaintiffs' claim.

In two other cases, however, the First Amendment was not an absolute bar to tort liability for nonlibelous negligent statements. In Weirum $v$. RKO General, Inc. ${ }^{16}$ the Supreme Court of California held a radio station liable for the death of a motorist forced off the road by two speeding teen-agers who were participating in the station's promotional contest to find a roving disc jockey. The court rejected the defendant's First Amendment defense:

Defendant's contention that the giveaway contest must be afforded the deference due society's interest in the First Amendment is clearly without merit. The issue here is civil accountability for the foreseeable results of a broadcast which created an undue risk of harm to decedent. The First Amendment does not sanction the infliction of physical injury merely because achieved by word, rather than act. ${ }^{17}$

Weirum's reasoning was apparently followed in Carter v. Rand McNally $\mathbb{E}^{\mathrm{C} C o},{ }^{18}$ a case in which a science textbook's failure to warn of the dangers of an experiment resulted in physical injury to an eighth-grade student. The judge did not grant summary judgment, suggesting that the First Amendment was not seen as an absolute bar to recovery. ${ }^{19}$

While these four cases are the most important in the area, they are by

247 Ga. at 404 n.2, 276 S.E.2d at 582 n.2.

13. 446 A.2d 1036 (R.I. 1982).

14. 395 U.S. 444 (1969) (per curiam).

15. The Brandenburg "incitement" standard is presented infra note 31 .

16. 15 Cal. 3d 40, 539 P.2d 36, 123 Cal. Rptr. 468 (1975).

17. Id. at 48,539 P.2d at $40,123 \mathrm{Cal}$. Rptr. at 472 (emphasis added). While the court was certainly concerned about the possibility of "unwarranted extensions of liability," it felt that the "spectacular" circumstances of the case would prevent such unbridled extensions. Id. at 48, 539 P.2d at $40-41,123$ Cal. Rptr. at $472-73$.

18. No. 76-1864-F (D. Mass. Sept. 4, 1980). This case is the subject of a number of recent articles. See, e.g., Conrad, New Problems in Publisher Liability, AB Bookman's WeEkLy, May 18, 1981, at 3894; Swartz, You Can't Judge a Book By Its Conver, Trial, Nov. 1981, at 89; Wallis, supra note 10; McQuaid, Publisher of Science Text Held Liable for Inadequate Laboratory Instructions, Chron. Higher Educ., July 27, 1981, at 13, col. 2.

19. A jury eventually returned a substantial verdict for the plaintiff. See Wallis, supra note 10 , at 209. The case, however, is not officially reported. 
no means the only attempts to extend tort liability to nonlibelous negligent statements. ${ }^{20}$ There has been a gradual increase in the incidence of such suits and, given the language in Weirum and the large recovery in Carter, ${ }^{21}$ many more such suits are likely to be filed in the future.

This burgeoning area of the law presents a troublesome dilemma. In these cases, courts must balance the interest of society in compensating injured parties against the freedom of speech guaranteed by the First Amendment. The disparate conclusions reached by the courts to date illustrate the difficult choices these cases require.

\section{ANalysis of the Approaches to the Dilemma}

Both the Brandenburg standard and the related "clear and present danger" test effectively bar recovery. If courts were to emphasize tort principles, however, liability would often be imposed. ${ }^{22}$ The First Amendment would limit recovery only in certain situations. The inappropriateness of applying the Brandenburg standard, and the utility of common law tort principles, as exemplified by the law of libel, suggest that the latter approach is more appropriate to the statements at issue.

\section{A. The Inapplicability of Brandenburg}

The "incitement" standard articulated in Brandenburg $v$. Ohio ${ }^{23}$ apparently reformulates the "clear and present danger" test ${ }^{24}$ of Schenck $v$.

20. Sep, e.g., Demuth Dev. Corp. v. Merck \& Co., 432 F. Supp. 990 (E.D.N.Y. 1977) (publisher of drug index that misstated toxicity of chemical disinfectant held not liable to drug manufacturer); Cardozo v. True, 342 So. 2d 1053 (Fla. Dist. Ct. App.) (bookseller not liable to purchaser for harm caused by cookbook's failure to warn about poisonous ingredients), cert. denied, 353 So. 2d 674 (Fla. 1977); Yuhas v. Mudge, 129 N.J. Super. 207, 322 A.2d 824 (App. Div. 1974) (defendant not liable to reader for harm caused by fireworks advertised in defendant's magazine); Young v. Mallet, 49 A.D.2d 528, 371 N.Y.S.2d 1 (1975) (action for personal injuries incurred from following advice in pamphlet dealing with vitamin consumption dismissed as to author for want of jurisdiction); Roman v. City of New York, 110 Misc. 2d 799, 442 N.Y.S.2d 945 (Sup. Ct. 1981) (wrongful conception claim based on alleged negligent misrepresentation in booklet concerning contraception dismissed for lack of any duty owed to defendant); Waiter v. Bauer, 109 Misc. 2d 189, 439 N.Y.S.2d 821 (Sup. Ct. 1981) (court denied motion to amend complaint to include strict liability claim where plaintiff was injured as a result of science textbook's failure to warn of dangers involved in experiment), modified, 88 A.D.2d 787, 451 N.Y.S.2d 533 (1982).

21. According to his attorney, the plaintiff "ultimately [recovered] $\$ 1.1$ million." Swartz, supra note 18 , at 110 n.2. Of this amount, the publisher apparently paid $\$ 100,000$, and the teacher's insurance company the remaining $\$ 1$ million. See Wallis, supra note 10, at 209; McQuaid, supra note 18, at 13 , col. 2 .

22. Liability will be imposed, of course, only when the tort requirements of negligence, legal causation, and damage are met.

23. 395 U.S. 444 (1969) (per curiam).

24. It is unciear what effect the Brandenburg decision has actually had on the vitality of the "clear and present danger" test. In concurring opinions, Justices Black and Douglas read the decision as rejecting this doctrine. Id. at 449-50 (Black, J., concurring); id. at 450-57 (Douglas, J., concurring). The majority opinion itself, however, never mentions the "clear and present danger" test. See generally Comment, Brandenburg v. Ohio: A Speech Test For All Seasons?, 43 U. ChI. L. Rev. 151, 
United States. ${ }^{25}$ From Schenck through Brandenburg, the Court has attempted to fashion a standard for speech that advocates action inimical to the public welfare ${ }^{26}$ or to the security of the government. ${ }^{27}$ While not inherently limited to "political" speech, the standards in this area have most often been applied in that context. Schenck, for example, involved a criminal conviction for distributing a leaflet opposing World War I and the draft, while a number of later cases dealt with speech advocating the forcible overthrow of the government. ${ }^{28}$ Such speech is clearly political ${ }^{29}$ and lies at the "core"so of the First Amendment. It is to this "core" that Brandenburg typically applies.

While Brandenburg provides essential First Amendment protections, an unlimited application of this standard would be improper. Brandenburg's "incitement" standard is limited to cases in which a statement encourages the use of force or the violation of law. ${ }^{31}$ Admittedly, this standard potentially covers many kinds of speech. "Advocacy," for example, while clearly including explicit statements of support and encouragement, arguably also extends to almost any portrayal, whether or not it was actually intended as a form of encouragement. "Law violation" also

158-64 (1975) (discussing relationship of the Brandenburg decision to "clear and present danger" test).

25. 249 U.S. 47,52 (1919).

26. Sep American Communications Ass'n v. Douds, 339 U.S. 382, 394-95 (1950) (indicating that "clear and present danger" test has been used to determine extent to which "First Amendment permits the suppression of speech which advocates conduct inimical to the public welfare").

27. See Dennis v. United States, 341 U.S. 494 (1951) (upholding convictions for conspiring to advocate the overthrow of the government).

28. See, e.g., Yates v. United States, 354 U.S. 298 (1957) (overturning convictions of Communist leaders charged under Smith Act with conspiring to advocate and teach the duty and necessity of violently overthrowing federal government); Dennis v. United States, 341 U.S. 494 (1951) (upholding convictions under the Smith Act). For a discussion of these and related cases, see Comment, supra note 24 , at $151-57$.

29. But see Bork, Neutral Principles and Some First Amendment Problems, 47 IND. L.J. 1, 31 (1971) ("Advocacy of law violation is a call to set aside the results that political speech has produced.").

30. The centrality of political speech to the First Amendment is recognized by the Supreme Court. See NAACP v. Claiborne Hardware Co., 458 U.S. 886, 915 (1982) ("[P]olitical speech [lies] at the core of the First Amendment.'") (quoting Henry v. First Nat'l Bank, 595 F.2d 291, 303 (5th Cir. 1979), cert. denied, 444 U.S. 1074 (1980)); see also Carey v. Brown, 447 U.S. 455, 467 (1980) (indicating that expression on public issues "has always rested on the highest rung of the hierarchy of First Amendment values").

31. In Brandenburg, the Court held that:

[T] he constitutional guarantees of free speech and free press do not permit a State to forbid or proscribe advocacy of the use of force or of law ziolation except where such advocacy is directed to inciting or producing imminent lawless action and is likely to incite or produce such action.

395 U.S. 444, 447 (1969) (per curiam) (emphasis added).

32. Spe Kingsley Int'l Pictures Corp. v. Regents of the Univ. of N.Y., 360 U.S. 684, 688-89 (1959) (characterizing movie's portrayal of adultery as advocacy in determining whether such portrayals fall within First Amendment definitions of protected speech); Joseph Burstyn, Inc. v. Wilson, 343 U.S. 495, 501 (1952) (referring to "subtle shaping of thought which characterizes all artistic expression"); Winters v. New York, 333 U.S. 507, 510 (1948) ("What is one man's amusement, teaches 
can be interpreted broadly. It conceivably includes both criminal and tortious conduct, as well as any other "substantive evils that Congress has a right to prevent."

Brandenburg should not be applied to nonlibelous negligent speech, however, for these statements do not specifically encourage violation of the law. By definition, such speech results in harm because of negligence on the part of the speaker. A "wrong" is not "advocated" as it is in the case of speech properly within the realm of Brandenburg. ${ }^{34}$ Moreover, under the Brandenburg standard, the imposition of liability becomes more likely as the expression becomes more effective, while with negligent statements, the imposition of liability becomes more likely as the expression becomes less effective. ${ }^{35}$ Finally, liability for negligent statements does not depend on whether the government approves or disapproves of the idea conveyed by the message.

\section{B. Libel Law: The Utility of Common Law Tort Principles}

The inapplicability of the Brandenburg standard to nonlibelous negligent statements and the growing number of cases involving such statements demand the development of a different standard. Common law tort principles, which will limit, rather than bar, access to judicial remedies, are more appropriate than the Brandenburg standard. An analysis of libel law especially suggests the utility of using tort principles in the First

another's doctrine."). See generally Note, Tort Liability of the Media for Audience Acts of Violence: A Constitutional Analysis, 52 S. CAL. L. Rev. 529, 556-67 (1979) (discussing meanings of "advocacy" and "incitement" in context of television violence).

33. Schenck v. United States, 249 U.S. 47, 52 (1919).

34. The distinction between negligent statements and ones that "advocate" violation of the law can be illustrated by a comparison of DeFilippo v. National Broadcasting Co., 446 A.2d 1036 (R.I. 1982), with Olivia N. v. National Broadcasting Co., 126 Cal. App. 3d 488, 178 Cal. Rptr. 888 (1981), cert. denied, 458 U.S. 1108 (1982). At first glance, these cases appear to be very similar. In Olinia $N$., the plaintiff alleged that her rape was stimulated by the defendants' broadcast of a fictional rape scene. The California Court of Appeal denied recovery since the plaintiff had failed to prove "incitement" as defined in Brandenburg \%. Ohio. See id. at 494-95, 178 Cal. Rptr. at 892-93.

Although DeFilippo used the same standard, the defendants in Olivia $N$. advocated illegal action, whereas DeFilippo's hanging stunt was not illegal. The movie at issue in Olivia $N$. portrayed, and thus "advocated," a rape-clearly an illegal act. In DeFilippo, on the other hand, the portrayal involved only a hanging stunt. If done properly, as it was on the program in question, such a stunt is neither illegal nor tortious. Thus, the application of the Brandenburg standard was arguably proper in Olivia $N$. since the "advocacy" of some type of law violation was involved. The use of the "incitement" standard in DeFilippo, however, was inappropriate since the case involved no advocacy of illegal or tortious action.

35. Assume, for example, that some revolutionary desires to arm his forces with Molotov cocktails. With this in mind, he publishes a manual containing instructions on how to make these devices. If these instructions are negligent, such that the instructions cannot possibly create functioning Molotov cocktails, and the followers are injured while attempting to make the devices, the imposition of liability will be on speech that is very ineffective. With Brandenburg, on the other hand, liability will typically by imposed only on very "effective" speech. By definition, there can be liability only where the advocacy is directed to producing, and is likely to produce, imminent lawless action. Thus, as the revolutionary becomes more adept at, say, inciting the masses, liability becomes more likely. 
Amendment area. This is instructive, for nonlibelous negligent statements are similar in many respects to libelous speech.

\section{Libel Law}

Tort law has already developed a framework that balances First Amendment protection with the need to compensate an injured plaintiff. Since New York Times Co. v. Sullivan, ${ }^{36}$ the Court has granted a broad First Amendment protection to libelous speech through common law privilege. ${ }^{37}$ Rather than substitute a new set of First Amendment standards for existing tort principles in libel, ${ }^{38}$ the Sullivan Court expanded the traditional privilege of "fair comment" to give proper First Amendment protection to those who comment on the conduct of public officials. ${ }^{30}$ This approach of "adjusting" tort principles to bring them into alignment with the First Amendment led, in subsequent cases, to the relaxation of the common law's treatment of libel against public ${ }^{40}$ and private ${ }^{41}$ figures.

The system of libel law that has emerged from this process of adjustment has been lauded by a range of commentators. ${ }^{42}$ This success demon-

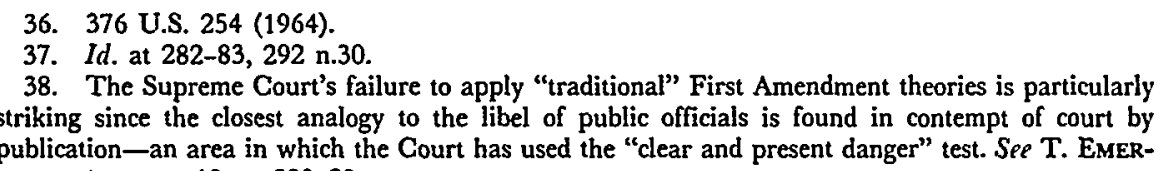
SON, supra note 10 , at 528-29.

39. The Court quoted at length from a state supreme court decision dealing with a public official allegedly defamed by the publication of inaccurate factual assertions:

In such a case the occasion gives rise to a privilege, qualified to this extent: any one claiming to be defamed by the communication must show actual malice or go remediless. This privilege extends to a great variety of subjects, and includes matters of public concern, public men, and candidates for office.

376 U.S. at 281-82 (quoting Coleman v. MacLennan, 78 Kan. 711, 723, 98 P. 281, 285 (1908)). At the time of Coleman, this common law privilege of "fair comment" was not generally applicable to false statements of fact. See W. Prosser, HANDBOOK OF THE LAW OF TORTS § 118, at 819-20 (4th ed. 1971) (indicating that most states restricted the privilege to statements of opinion). The Sullitan Court, however, held that the Constitution required this expanded version of the privilege. "[S]uch a privilege [for criticism of official conduct]," the Court stated, "is required by the First and Fourteenth Amendments." 376 U.S. at 283.

40. In Curtis Publishing Co. v. Butts, 388 U.S. 130 (1967), for example, a qualified privilege was extended to those who make false statements of fact about "public figures." The common law privilege of "fair comment," which was arguably applicable to "public figures," see W. Prosser, supra note $39, \S 118$, at $828-29$, had generally been limited to statements of opinion. See id. $\S 118$, at 819-20.

41. In Gertz v. Robert Welch, Inc., 418 U.S. 323 (1974), the Court held that when the subject of a libelous statement is a private figure, the defendant's conduct must be at least negligent in order for liability to be imposed. Id. at 347 ("We hold that, so long as they do not impose liability without fault, the States may define for themselves the appropriate standard of liability for a publisher or broadcaster of defamatory falsehood injurious to a private individual.") (emphasis added). The common law rule, by contrast, had essentially been one of strict liability. See W. ProssER, supra note $39, \S 113$, at $772-74$.

42. See, e.g., T. EMErson, supra note 10, at 529 ("The libel cases . . represent a significant advance in the treatment of First Amendment issues."); Robertson, Defamation and the First Amendment: In Praise of Gertz v. Robert Welch, Inc., 54 TEX. L. REv. 199, 200-01 (1976) (supporting 
strates the utility of applying tort principles in the balancing process. By tightening or loosening common law standards in accordance with the First Amendment's mandates, tort law permits the compensation of injured parties without contravening First Amendment principles.

\section{Analogy to Nonlibelous Negligent Statements}

Nonlibelous negligent statements have many similarities to libelous speech, ${ }^{43}$ especially to "private" libel resulting from negligence by the speaker. The injury in both instances will be the result of a breach of a duty to exercise care in the use of language. Furthermore, in both situations the harm will typically be both unintended and unexpected. These similarities suggest that liability should be allowed to a comparable extent in both cases.

In addition, in allowing civil liability to be imposed for the tort of libel, the Supreme Court has recognized a "strong and legitimate state interest in compensating private individuals for injury to reputation."14 Since a similar, and perhaps more compelling, state interest exists in protecting individuals from physical injury, a state should be allowed to impose tort liability where a negligent statement in a publication results in such harm.

Finally, as with the tort of libel, the proposed liability for nonlibelous negligent statements does not depend upon whether the government approves or disapproves of the idea ${ }^{45}$ presented in the message. For example,

Court's intrusion into domain of private libel as sensible "compromise between . . . strongly opposed and significant values").

43. The analogy between nonlibelous negligent statements and libelous speech is, admittedly, imperfect. For example, with many libelous statements the harm is intended, whereas, by definition, this is not the case with respect to nonlibelous negligent statements. Furthermore, while it is arguably the libelous words themselves that do the damage, a nonlibelous negligent statement will typically cause harm only if there is some subsequent act of reliance. But $c$. Phillips, Product Misrepresentation and the First Amendment, 18 Idaho L. Rev. 395, 409 (1982) (suggesting that, for First Amendment purposes, misrepresentation and libel are quite similar since "[i]n either case, misplaced reliance on false speech causes forseeable [sic] injury") (emphasis added).

The differences, however, do not significantly undercut the analogy. For example, since no liability will be imposed unless the subsequent act was so foreseeably likely that the speech presented an unjustifiable risk of harm, it is not crucial to the analogy that no harm will result from a nonlibelous negligent statement unless there is some subsequent act. A substantial link between the words and the harm is clearly required.

44. Gertz v. Robert Welch, Inc., 418 U.S. 323, 348-49 (1974).

45. The proposed liability for nonlibelous negligent statements would, of course, deter the "content" of the message as opposed to the time, place or manner in which it is communicated. See $L$. Tribe, AMerican Constrtutional. Law § 12-2, at 580-84 (1978). Thus, a more stringent First Amendment analysis is required than would be the case if only noncommunicative impact were being regulated.

The "content" of a message, however, must be distinguished from the "idea" it presents. For example, were an author to suggest that, in order to become more politically active, women should take massive doses of vitamin $A$, and were this diet to injure those who undertook it, the author would be liable. Clearly, this imposition of liability implicates the content of the message. The words themselves, not the time or place of their communication, led to the injury. But the "idea" presented-greater political participation for women-is not subject to liability. 
if a book on how to raise the American flag contains faulty instructions that lead to physical injury, the author will be liable for damages even though the government may well approve of the general idea of the book.

These analogies between nonlibelous negligent statements and libelous speech suggest that a tort standard should be applied to nonlibelous statements. ${ }^{48}$ The preceding analysis of libel law suggests that tort law will facilitate a proper balancing of the First Amendment and the plaintiff's need for compensation. Neither the Brandenburg standard nor the "clear and present danger" test would allow a comparable balancing.

\section{MisRepresentation LAW}

Of the available tort standards, those for misrepresentation seem most appropriate for nonlibelous negligent statements. ${ }^{47}$ Misrepresentation law has developed in light of the need to limit potential liability for negligent speech; ${ }^{48}$ consequently, a coherent and sufficiently restrictive body of law already exists for speech that causes economic harm. Insofar as it relates to statements that result in physical harm, however, misrepresentation law is less well developed. An analysis of the existing misrepresentation standards in this latter area nonetheless reveals that, when considered along with more general tort principles, the law of misrepresentation provides an appropriate standard.

\footnotetext{
Admittedly, the taking of vitamins could also be seen as the "idea." Such an argument, however, misperceives what is being punished. One is entitled to advocate the taking of massive doses of vitamin A. If one undertakes to "educate" the public in this way, however, the users must be apprised of the dangers involved. The state is not so much suppressing speech as it is requiring more speech-i.e., a warning.

46. One possible alternative is to characterize the harmful words as "conduct" or "speech combined with conduct." A characterization such as this would arguably circumvent First Amendment concerns. See Rountree, supra note 10, at 63 (suggesting that Shannon court "overlooked the inviting option of treating the performance on television as conduct and not speech, or at least as conduct combined with speech"). Most commentators reject this alternative, however. See, e.g., J. ELY, DEMOCRACY AND DISTRUST 109 (1980) (characterization as "speech plus" is "simply not responsible"); L. TRIBE, supra note $45, \S 12-7$, at 598-601 (indicating that dichotomy between speech and conduct is persistent but unhelpful); Farber, Commercial Speech and First Amendment Theory, 74 Nw. U.L. REv. 372, 406 (1979) ("First amendment theories based on the distinction between speech and conduct have never been very successful.").
}

47. Cf. McDermott, Liability for Negligent Dissemination of Product Information: A Proposal for Assuring a More Responsible Writership, 18 FoRUM 557, 564-72, 576 (1983) (suggesting utility of misrepresentation law for negligent statements).

48. See, e.g., Ultramares Corp. v. Touche, 255 N.Y. 170, 179, 174 N.E. 441, 444 (1931) (expressing concern over prospect of "liability in an indeterminate amount for an indeterminate time to an indeterminate class"); W. PROSSER, supra note $39, \S 107$, at 708 ("The spectre of unlimited liability, with claims devastating in number and amount crushing the defendant because of a momentary lapse from proper care, has haunted the courts."). 


\section{A. The Applicability of Misrepresentation Law}

While almost any misuse of language-whether negligent or intentional-could conceivably be classified as a misrepresentation, tort law actually classifies very few types of tortious conduct as misrepresentation per se. ${ }^{40}$ Misrepresentation is typically recognized as a distinct form of tort liability only if the plaintiff has suffered economic harm. ${ }^{50}$ Where a noneconomic injury has been suffered, the fact that it has been caused by speech, rather than some other act, is rarely taken into account. This failure to focus on the speech and misrepresentation elements of the conduct blurs any potential First Amendment analysis. Consequently, this Note explicitly takes into account the incidence of speech and the specific form that the speech takes.

Of the statements at issue in this Note, almost all can be classified as "misrepresentations" in the sense of speech that misstates the situation such that the plaintiff is led to place himself or his property in danger of harm. ${ }^{\text {B1 }}$ Misrepresentations are typically in the form of positive assertions. ${ }^{52}$ Nondisclosure, however, such as a failure to warn, can also amount to misrepresentation. ${ }^{53}$ The statements in Shannon, DeFilippo, Weirum, and Carter can thus be analyzed as "misrepresentations," since the harm typically resulted from the defendant's failure to warn of the danger presented or, more explicitly, from his failure adequately to contradict an appearance of safety. ${ }^{54}$

\footnotetext{
49. As the Restatement (Second) of Torts explains:

Misrepresentation runs all through the law of torts as a method of accomplishing various types of tortious conduct which, for reasons of historical development or as a matter of convenience, usually are grouped under categories of their own. Thus a battery may be committed by feeding the plaintiff poisoned chocolates or inducing his consent to a physical contact by misrepresenting its character. . . . Many of the common forms of negligent conduct . . . are in their essence nothing more than misrepresentation, as in the case of a misleading signal by a driver of an automobile about to make a turn or an assurance that a danger does not exist.
}

III Restatement (SECOND) of ToRTs 54 (1977) (scope note to ch. 22) (emphasis added).

50. See id. ("So far as misrepresentation has been treated as giving rise in and of itself to a distinct form of tort liability, it has been concerned and identified with resulting pecuniary loss.").

51. Cf. W. Prosser, supra note $39, \S 33$, at 178 (describing situations in which a speaker will be liable for negligent use of language).

52. See id. $\S \S 33,106$, at $177-79,694-95$ (suggesting positive misrepresentations can take various forms).

53. See J. Fleming, The Law of Torts 161 (4th ed. 1971) ("often enough the misrepresentation consists, not in something [the defendant] said, but in his failing to say anything at all (i.e., to warn)"); W. Prosser, supra note 39, § 33, at 179 ("In many situations, a failure to disclose the existence of a known danger may be the equivalent of misrepresentation . . . ."); Phillips, Product Misrepresentation and the Doctrine of Causation, 2 HoFsTRA L. REv. 561, 571 (1974) ("Representations may be inadequate because of either partial insuficiency [sic] or total failure to warn or direct.").

54. Cf. Maize v. Atlantic Ref. Co., 352 Pa. 51, 55-56, 41 A.2d 850, 852 (1945) (prominent display of product name, "Safety-Kleen," and relatively inadequate warning combined to give product misleading appearance of safety); J. Fleming, supra note 53, at 161 ("Misrepresentations of safety are a common cause of personal injury ... . which the law has long considered actionable, as in the case of dangerous premises and products concealing a trap or flaw beneath a misleading appearance of 
Misrepresentations, of course, do not receive full First Amendment protection. ${ }^{55}$ They fall instead into that "category of utterances which 'are no essential part of any exposition of ideas, and are of such slight social value as a step to truth that any benefit that may be derived from them is clearly outweighed by the social interest in order and morality." "\$B This description has been used to justify the imposition of tort liability for libelous speech. Since, as shown earlier, libelous speech is analogous to the speech at issue in several important respects, it is reasonable to see this description as equally applicable to nonlibelous negligent statements.

\section{B. Misrepresentation Law as It Currently Exists}

Having established that the imposition of tort liability for nonlibelous negligent speech is not repugnant to the Constitution and that misrepresentation law provides an appropriate frame of analysis, the Note will now examine the limits imposed by misrepresentation law on potential liability.

\section{Misrepresentation Law-Economic Harm}

To recover damages, ${ }^{57}$ a plaintiff must prove: (1) that the defendant had a duty to exercise care in the use of his language and that he breached this duty (a combination that amounts to a negligent misrepresentation) $;^{58}(2)$ that the plaintiff justifiably relied on the misrepresentation; ${ }^{58}$ and (3) that actual monetary loss resulted. ${ }^{60}$ While these elements clearly parallel those of a typical negligence action, there are three significant restrictions. First, there is no general duty to exercise care in the use of language when only pecuniary interests are at stake. ${ }^{61}$ Some "special relationship" between the parties must exist in order for such a duty to

security.").

55. Sep Konigsberg v. State Bar, 366 U.S. 36, 49 n.10 (1961) (suggesting that "libel, slander, misrepresentation, . . . false advertising . . . and the like" are not accorded full First Amendment protection) (emphasis added); Olivia N. v. National Broadcasting Co., 74 Cal. App. 3d 383, 388, 141 Cal. Rptr. 511,514 (1977) (same), cert. denied, 435 U.S. 1000 (1978).

56. Gertz v. Robert Welch, Inc., 418 U.S. 323, 340 (1974) (quoting Chaplinsky v. New Hampshire, 315 U.S. 568, 572 (1942)).

57. While economic harm can be caused by either fraudulent or negligent misrepresentations, see W. Prosser, supra note $39, \S 107$, at $700-10$, the analysis in this Note is restricted to negligent misrepresentations since they are the most relevant to the matter at hand.

58. Spe id. $\$ 107$, at 704-10.

59. See id. $\S 108$, at 714-18. This is essentially the legal causation requirement.

60. See id. $\$ 110$, at 731-33. For a general discussion of the elements of a negligent misrepresentation action where pecuniary loss is involved, see RESTATEMENT (SECOND) OF TORTs $\S 552$ (1977).

61. Sep 1 F. HARper \& F. James, The LAw OF TorTs $\S 7.6$, at 545 (1956):

The physical affairs of life are conducted on the assumption that everyone will so regulate his conduct as not unduly to expose another to risk of harm to person or property. The law, therefore, imposes the general duty of care. It is otherwise, however, as to the use of language which, if relied upon, is likely to affect adversely another's pecuniary interest . . . . 
arise. $^{62}$ A "special relationship" will generally be found only if there is privity of contract between the parties, or if the parties are engaged in some type of business or professional relationship at the time of the statement, or if the defendant has some pecuniary interest in making the statement. $^{\text {.83 }}$

The duty to use care in speaking is even further restricted with respect to third persons. The defendant generally will be liable only to a "limited group of persons" whom he intends to reach with the information, or whom he knows the recipient intends to reach. ${ }^{64}$

Finally, the plaintiff's reliance on a statement will generally not be seen as justifiable if he relies on an "opinion" as opposed to a statement of fact. ${ }^{68}$ If, however, a recognized expert gives a negligent opinion on a point within his expertise, then the general rule against liability may not apply. ${ }^{\text {68 }}$

\section{Misrepresentation Law-Physical Harm}

When an unpublished, negligent misrepresentation causes a physical injury, there are few special restrictions on recovery. ${ }^{67}$ In order for the plaintiff to recover for physical damage caused by the negligent use of language, he typically needs to prove only the general tort elements of duty, a breach of that duty, and damage legally caused by the breach. ${ }^{68}$

62. Id. ("Whereas one is always under a duty not, by his act, to threaten unreasonable harm to another's person or tangible property, there must be some special relationship between the parties, to create such a duty in respect to misinformation negligently given.").

63. Sep, e.g., International Prods. Co. v. Erie R.R., 244 N.Y. 331, 338, 155 N.E. 662, 664 (contractual relationship is one relationship that may lead to duty to use care in speaking), cert. denied, 275 U.S. 527 (1927); 1 F. HARPER \& F. JAMEs, supra note 61, $\S 7.6$, at 546 (business or professional relationship may require care in the use of language).

64. Restatement (SeCOND) of ToRTS § 552(2) (1977); $c$. Ultramares Corp. v. Touche, 255 N.Y. 170, 189, 174 N.E. 441, 448 (1931) ("liability for negligence. . . is bounded by the contract, and is to be enforced between the parties by whom the contract has been made"). Under the Restate$m e n t$, it is not required that the defendant know, at the time the information is supplied, the precise identities of the people in the limited group. RestatemENT (SECOND) of ToRTs $\S 552$ comment $h$ (1977).

65. Sep Dawson v. Graham, 48 Iowa 378, 380 (1878) ("In mere matters of opinion, every one is presumed to rely upon his own judgment."); 1 F. HARPER \& F. JAMES, supra note 61, § 7.8, at 559 ("One. . . type of representation that the courts have held ordinarily not of a type to justify reliance, is a statement .. . [of] opinion."). Facts are statements that "relate[ ] to an event or state of affairs which either exists at the present moment or has had a past existence . . . if that event or state of affairs is susceptible of knowledge." Id. $\S 7.8$, at 560 (footnotes omitted). Opinions do not satisfy this standard.

66. See, e.g., Board of Water Comm'rs v. Robbins, 82 Conn. 623, 74 A. 938 (1910) (engineer); Bailey v. London Guar. \& Accident Co., 72 Ind. App. 84, 121 N.E. 128 (1918) (physician); sep generally 1 F. HARPER \& F. JAMES, supra note $61, \S 7.8$, at 561-62 (discussing circumstances in which courts will modify general rule against liability).

67. As Professor Prosser points out, "[M]isrepresentation frequently occurs in ordinary negligence actions for personal injuries or property damage . . . and the courts have not found it necessary to distinguish it in any way from any other negligence." W. PROSSER, supra note $39, \S 107$, at 704.

68. See Restatement (Second) of Torts § 311 (1965); W. Prosser, supra note 39, § 33, at 
Two qualifications are necessary, however. First, as with statements that cause economic harm, some form of "special relationship" must be shown before a duty to exercise care in the use of language arises. ${ }^{69}$ Where the injury is to some tangible interest, however, this special relationship is not nearly so restrictive as it is in the case of economic harm. ${ }^{70}$ The only general requirement appears to be that the communication must be intended as a statement upon which people should act. ${ }^{71}$

Second, the plaintiff's reliance on the statement must be justifiable in order for there to be legal causation. As in the case of economic harm, the plaintiff's reliance will generally not be seen as justifiable if he relies on a nonexpert "opinion," as opposed to a fact. ${ }^{72}$

Courts have had little trouble in applying the misrepresentation standard to unpublished misrepresentations and imposing liability for negligent speech. For example, if the plaintiff relies on an unpublished assurance that a bridge is safe, or that there is no danger from blasting operations, and is then injured as a result of this reliance, he is likely to recover. ${ }^{73}$ Where the misrepresentation is published and the First Amendment thereby brought into focus, however, liability is no longer clear, as is apparent from Shannon and DeFilippo. ${ }^{74}$

177-80.

69. See supra note 62; see also W. Prosser, supra note $39, \S 33$, at 179 ("In all cases of negligent misrepresentation . . . the circumstances must be such that the defendant is under a duty to the plaintiff to exercise reasonable care in giving the information ....").

70. The physical harm standard is also less restrictive than the economic harm standard in another area. With respect to third persons, the duty to use care in the use of language that might cause physical injury extends to all those foreseeably injured by the statement. See Pabon v. Hackensack Auto Sales, Inc., 63 N.J. Super. 476, 498, 164 A.2d 773, 784 (App. Div. 1960); J. Fleming, supra note 53, at 162-63. This is clearly less restrictive than the "limited group of persons" standard used when economic injury is involved.

71. One generally accepted statement of this proposition is that: "There must be knowledge or its equivalent that the information is desired for a serious purpose; that he to whom it is given intends to rely and act upon it; that if false or erroneous he will because of it be injured in person or property." International Prods. Co. v. Erie R.R., 244 N.Y. 331, 338, 155 N.E. 662, 664, cert. denied, 275 U.S. 527 (1927). "Subjective" intent to have the audience act, however, is not strictly required. As the International Products case points out, there must be "knowledge or its equiz'alent." Id. (cmphasis added). One generally accepted equivalent of knowledge is "substantial certainty." See REsTATEMENT (SECOND) of TORTs \& 8A (1965); see also Garratt v. Dailey, 46 Wash. 2d 197, 279 P.2d 1091 (1955) (suggesting that, if defendant was substantially certain that harm would result, intent requirement for battery would be met even though defendant never desired the result). Thus, where the speaker is substantially certain that his words will be relied and acted upon, his lack of subjective intent should not be seen as insulating him from potential liability.

72. See, e.g., Hauter v. Zogarts, 14 Cal. 3d 104, 111, 534 P.2d 377, 381, 120 Cal. Rptr. 681, 685 (1975) ("If defendants" assertion of safety is merely a statement of opinion . . . they cannot be held liable for its falsity."); Pabon v. Hackensack Auto Sales, Inc., 63 N.J. Super. 476, 497, 164 A.2d 773, 784 (App. Div. 1960) (suggesting that only "factual report[s]" and "expert opinion[s]" are actionable).

73. Sep W. Prosser, supra note $39, \S 33$, at 178.

74. In this Note, "published" speech refers to that speech which is in a fairly "permanent" form or which has received wide distribution. A book, a newspaper article, a movie, and a television broadcast are all forms of "published" speech. The First Amendment, of course, does not distinguish between unpublished and published speech although the distinction is currently relevant in tort law. 
To allow the First Amendment to be an absolute bar to recovery in the case of published misrepresentations, however, would seem strange indeed. For example, imposing liability when the assurance of safety is given personally by some flagman but not when the assurance is disseminated through pamphlets makes no sense, because the defendant is likely to endanger more people by publishing the information in pamphlet form. Thus, while the First Amendment should be taken into account in this situation, it should be seen as limiting the scope of tort liability rather than barring its imposition. The use of the misrepresentation standards that have been applied to "unpublished" speech would achieve this end.

\section{General Common Law Tort Principles}

As suggested by the law of misrepresentation, liability for negligent words that cause physical injury will be imposed only if the statement was both intended as a communication upon which people should act and presented in the form of a factual statement or expert opinion. While these principles imply substantial limitations, they are, by themselves, insufficient to keep liability within constitutional bounds. It is only when considered in connection with the full panoply of tort limitations on liability, particularly the many limitations on the duty to warn, that misrepresentation law sufficiently restricts liability for nonlibelous negligent speech.

The notion of a "duty to warn" is central to the potential liability for nonlibelous negligent statements: The negligence involved is generally a failure to warn of some danger. If this duty to warn were unduly burdensome, the First Amendment might well preclude liability. The duty to warn, however, is not unconstitutionally burdensome. While this duty is certainly expanding, ${ }^{75}$ it is far from universal-e.g., it does not even extend to all foreseeable injuries. Moreover, even when a duty to warn does exist, this duty is not typically seen as onerous.

The duty to warn is subject to a number of important limitations. ${ }^{76}$

Where a form of speech is "unpublished"-e.g., where a truck driver waves a following motorist on to pass-courts have little difficulty in imposing liability for any physical harm. See id. Where the speech is "published," however, the courts begin to balk because of the potential for unlimited liability. See, e.g., Walt Disney Prods. v. Shannon, 247 Ga. 402, 405, 276 S.E.2d 580, 583 (1981) (failure to provide absolute First Amendment protection would "open the Pandora's box"); DeFilippo v. National Broadcasting Co., 446 A.2d 1036, 1041-42 (R.I. 1982) (barring recovery after expressing concern over self-censorship that might result from allowing recovery).

75. See Noel, Products Defective Because of Inadequale Directions or Warnings, 23 Sw. L.J. 256, 264 (1969).

76. In discussing the duty to warn, Professor Prosser states:

[T] he seller is under a duty to give adequate warning of unreasonable dangers . . of which

he knows, or should know ....

One limitation commonly placed upon the duty to warn, or for that matter the seller's entire 
First, there is a duty to warn only if the potential danger is "unreasonable"-a determination to be made after balancing the expected harm against the difficulty of implementing an effective warning. ${ }^{77}$ The presence of speech should be taken into account as a factor tending to make the implementation of an effective warning even more difficult. ${ }^{78} \mathrm{~A}$ second limitation is that the speaker will be under a duty to warn only if he knows about the danger or has reason to know of it. ${ }^{79}$ Finally, there is no need to warn of dangers that are obvious, or should be obvious, to the person relying on the statement. ${ }^{80}$ Even when a duty to warn is found, the burden imposed is not typically oppressive. The warning "must be reasonably calculated to reach [the users of the product], directly or indirectly," ${ }^{81}$ and expressed in language sufficiently clear, emphatic, and prominent to alert the user to the potential danger. ${ }^{\mathbf{2 2}}$

\section{The Proposed Standard and Its Application}

The standard suggested by the above analysis is a general tort standard, modified by misrepresentation principles so as to take into account First Amendment protections. ${ }^{83}$ In an action to recover for physical injuries,

liability, is that he is not liable for dangers that are known to the user, or are obvious to him, or are so commonly known that it can reasonably be assumed that the user will be familiar with them.

W. Prossrer, supra note $39, \$ 96$, at $646-47,649$ (footnotes omitted).

77. See id. \$96, at 646-47; Noel, supra note 75, at 264-65.

78. The implementation should be seen as more "difficult" in the sense that a court should be much more reluctant to require a warning when speech, as opposed to, say, a consumer product, is involved. When speech is the "product," warnings can be extremely disruptive. A packet of instructions and warnings will often greatly dilute the impact of speech, whereas this packet may have little or no effect on the utility of a lawn mower.

79. Sep supra note 76; see also Restatement (SECOND) OF TORTS $§ 388$ (a) (1965) (supplier of chattel must inform those who use chattel of dangers of which he "knows or has reason to know").

80. See W. Prosser, supra note $39, \S 96$, at 649 . This limitation can be especially restrictive since, in determining what is "obvious," courts often look to the regular users of the product. See, e.g., Katz v. Arundel-Brooks Concrete Corp., 220 Md. 200, 204, 151 A.2d 731, 733 (1959) (warnings not required because ready-mixed concrete is customarily sold to builders familiar with its properties); Dalton v. Pjoneer Sand \& Gravel Co., 37 Wash. 2d 946, 948, 227 P.2d 173, 174-75 (1951) (dangers of cement mix are common knowledge, and thus no warning is required). If this group of users would consider the danger "obvious," then the potential danger would, under this approach, be considered "obvious" even to a totally inexperienced user of the product. See Noel, supra note 75, at 272-73 ("Where . . . the danger as well as the defect is evident to most users of a product, the courts are reluctant to find a duty to warn an occasional inexperienced user."). Thus, if seasoned picketers realized that the kind of demonstration in question generally led to violence, a novice demonstrator (with no reason to know of this incidence of violence) who was enticed to join the picket and then injured by the violence, may be unable to recover on a "failure to warn" claim on the ground that there was no duty to warn of this "obvious" danger.

81. Noel, supra note 75 , at 281.

82. See id. at 283-84.

83. The degree of protection suggested is a "middle range" of protection similar to that currently afforded commercial speech. In Virginia State Bd. of Pharmacy v. Virginia Citizens Consumer Council, 425 U.S. 748, 758-62 (1976), the Supreme Court distinguished Valentine v. Chrestensen, 316 U.S. 52 (1942), and unequivocally held that the First Amendment protects purely commercial speech, 
liability will be imposed only if the plaintiff establishes the following elements. First, the defendant must be shown to have owed some duty of care to the plaintiff in the use of his language. No such duty will be found unless, as required by misrepresentation law, the plaintiff proves that the defendant intended for the statement to be acted upon. General tort principles relating to duty would also apply when not inconsistent with this standard.

Second, there must be a breach of this duty amounting to negligence on the part of the defendant. ${ }^{84}$ This will often involve a failure adequately to contradict an appearance of safety created by the words in question.

Third, the plaintiff will be obliged to meet the requirement of legal causation. The plaintiff must prove that the statement inflicted a foresee-

though not as an absolute bar to the regulation of such speech.

Today, it is generally accepted that, while commercial speech is entitled to some degree of First Amendment protection, sfe, e.g., Bates v. State Bar, 433 U.S. 350, 379-82 (1977) (truthful, legitimate advertising of price and availability of routine legal services is entitled to some First Amendment protection); Bigelow v. Virginia, 421 U.S. 809, 818 (1975) (speech conveying information about a product or service which is legal where offered may not be totally banned), it can be subjected to more stringent regulation than would be permissible with respect to noncommercial speech. Compare National Soc'y of Professional Eng'rs v. United States, 435 U.S. 679, 698 (1978) (suggesting that speech furthering illegal price-fixing can be prohibited if the prohibition "represents a reasonable method of eliminating the consequences of the illegal conduct") with Brandenburg v. Ohio, 395 U.S. 444, 447 (1969) (per curiam) (requiring likelihood of imminent lawless action before advocacy of law violation can be proscribed).

Of particular relevance to this Note is the limited protection accorded to false or deceptive commercial speech. Justice Stewart has stated that such statements are analogous to the "false statements of fact" that, in the libel area, have been deemed unworthy of First Amendment protection. See Virginia State Bd. of Pharmacy, 425 U.S. at 775-81 (Stewart, J., concurring); see also Gertz v. Robert Welch, Inc., 418 U.S. 323, 340 (1974) ("no constitutional value in false statements of fact"). Justice Stewart reasoned that the regulation of false advertising will not deter truthful advertising. Virginia State $B d$. of Pharmacy, 425 U.S. at 777.

While not entirely persuasive, see Farber, supra note 46 (suggesting that contractual analysis of commercial speech is more coherent than Justice Stewart's analysis), Justice Stewart's explanation points out an important similarity between unprotected commercial speech and nonlibelous negligent statements. With both types of speech, the actionable words will generally be in the form of demonstrably false statements of fact. For example, the dangerous properties of chemicals used in a science experiment, or the probability of a balloon bursting if a BB is rotated inside, can be conclusively determined. A careful speaker will know these facts and, if they suggest an unreasonable danger, he will refrain from speaking or warn of the danger. It is when the speaker fails to do this that he is liable.

84. A finding of at least negligence is required since a strict liability standard is unlikely to be constitutionally acceptable. In the libel area, the Supreme Court has held that a defendant must be at least negligent in order for liability to be imposed. See supra note 41 . The similarities between libelous statements and the statements at issue, see supra pp. 751-52, suggest that this same standard is applicable here.

An important implication of this acceptance of some First Amendment protection for nonlibelous negligent statements is that the instructions and warnings provided by product manufacturers may also be entitled to such protection. For example, it may be unconstitutional to hold a manufacturer strictly liable for failing to warn of a product's dangerous nature. While this idea has not been accepted by the courts to date, see McDermott, supra note 47, at 572 ("No manufacturer has successfully advanced the theory that the directions he sold with his product merited First Amendment protection."); Phillips, supra note 43, at 400 ("a first amendment defense is for some reason thought inappropriate in products litigation involving failure to warn"), at least one commentator has suggested the propriety of First Amendment protection in this area, see id. 
able injury on a foreseeable plaintiff. The plaintiff must also show that his reliance on the statement was justifiable. Thus, as indicated in the misrepresentation analysis, the statement will typically have to be in the form of a fact or expert opinion.

Fourth, there must be an injury. Recovery should be strictly limited to actual harm ${ }^{85}$ to minimize the danger that this tort standard might be used to suppress protected speech. Finally, the plaintiff must prove that he was not contributorially negligent.

To illustrate the operation of the standard, three examples are considered.

Example 1. In DeFilippo v. National Broadcasting Co., ${ }^{88}$ a television talk show presented a hanging stunt wherein the host of the show was supposedly hanged. The plaintiffs' son imitated this stunt and died. The court used the Brandenburg "incitement" standard in this case and, after finding no "incitement," dismissed the suit. This use of the Brandenburg standard was improper since the activity encouraged (i.e., a hanging stunt) was neither illegal nor, if done properly, tortious. Misrepresentation law provides the proper standard. Even this standard, however, would preclude liability since the defendants did not intend that the viewers should act upon the stimulus. This lack of intent indicates that, in this case, there was no duty to use care in the use of language. ${ }^{87}$

Example 2. In Walt Disney Productions v. Shannon, ${ }^{88}$ a guest on a children's television show invited the children to experiment with sound effects by putting a BB inside a balloon. Plaintiff was injured when his balloon burst, propelling the BB into his eye. The proposed misrepresentation standard would impose liability (assuming no contributory negligence) since (a) the negligent statement at issue was a factual statement that was intended to induce action, and (b) there was a "proximately caused" injury.

85. Cf. Gertz v. Robert Welch, Inc., 418 U.S. 323, 349 (1974) (the "countervailing state interest extends no further than compensation for actual injury").

86. 446 A.2d 1036 (R.I. 1982).

87. The finding of no duty in this case is troubling since, as with many of the cases being examined, the injured party was a child. Furthermore, the cases under examination typically involve an invitation to participate in some potentially dangerous activity. See Wallis, supra note 10, at 222 ("the information in textbooks is more dangerous ... because a textbook actively invites the reader to perform potentially dangerous activities"). In tort law, these circumstances-infancy and "attraction"-will often lead to a duty where one otherwise would not exist. See W. Prosser, supra note $39, \S \S 33,59$, at 172-73, 364-66 (discussing "pied piper" cases and "attractive nuisance" doctrine). The proposed standard, however, should not include an exception to the "intent to act" requirement when children are involved. In this age of mass communication, almost any form of speech is potentially available to a very wide and diverse audience-an audience that is very likely to include infants. To allow infancy to circumvent the "intent to act" limitation would thus render it no real limitation at all. Authors would constantly have to worry about reliance even where none was intended, an excessive invasion of First Amendment rights.

88. $247 \mathrm{Ga} .402,276$ S.E.2d 580 (1981). 
Example 3. Assume that someone publishes the following statement: "In order to effect a change in government, people should make Molotov cocktails and throw them at the President." The segment of this statement that encourages people to throw Molotov cocktails at the President clearly involves the "advocacy of law violation" and thus is covered by the Brandenburg 7 . Ohio standard. The Brandenburg test, however, should not be applied to the part of the statement that encourages the mere making ${ }^{89}$ of Molotov cocktails since this is not, by itself, illegal or tortious. It is to this segment that the proposed standard should be applied.

If someone were injured while making a Molotov cocktail, a claim against the author of the "Make Molotov Cocktails" statement would most likely be based on the author's failure to warn of the dangers involved. A proper application of the proposed standard, however, would almost surely bar recovery. This is because there is apparently no "duty to warn" in this case. As stated earlier, there is no duty to warn of "obvious" dangers and it appears reasonable to conclude that the danger involved in making a bomb is "obvious." It should also be noted that the duty to warn is limited to "unreasonable" dangers, and it is unlikely that a statement that merely suggests the making of Molotov cocktails really presents such an unreasonable risk of harm. This is clearly different from the case where someone gives specific-and defective-instructions regarding the manufacture of a Molotov cocktail. ${ }^{90}$

These examples indicate the many restrictions placed on recovery. It is nonetheless possible that the proposed standard-essentially a tort standard modified to take into account First Amendment considerations-may chill certain types of speech. With a proper application of this standard, however, the speech which is chilled will be of the type that we want chilled-i.e., dangerously negligent statements that are really no part of the idea communicated. This result is reached because of the significant limitations placed on the imposition of liability. These limitations operate to restrict liability to such a narrow band of speech that it would

89. It is assumed that the mere making of Molotov cocktails is not, by itself, illegal. Legal manufacturing might include that for a benign experiment or an historical recreation of 1960 's violence.

90. It could be argued that the proposed standard will lead to undesirable consequences inasmuch as it will encourage speakers simply to leave out the instructions. This consequence, however, is actually one of the desired results of the standard. If the speaker is concerned about the propriety of his instructions, they should be eliminated. This will force the audience to consult a source that has been considered by the author to be acceptable for publication.

Overall, the system imposes no duty to provide instructions other than as already required by law. Where, however, one underlakes to provide instructions or information, there is a duty to exercise reasonable care. In this regard, it is similar to the duty to rescue. See Zelenko v. Gimbel Bros., 158 Misc. 904, 287 N.Y.S. 134 (Sup. Ct. 1935) (no general duty to rescue, but once a rescue is undertaken, it must be performed with reasonable care), aff'd, 247 A.D. 867, 287 N.Y.S. 136 (1936); Restatement (SkCond) of Torts $\S \S 314,323-24$ (1965) (same); W. Prosser, supra note 39, § 56 , at 340, 343-44 (same). 
be extremely difficult for the state to use the proposed standard to suppress protected speech. The use of the proposed standard, then, will allow for the compensation of many of the victims of published negligent statements while still keeping liability within constitutional bounds.

-Steven J. Weingarten 